\title{
http://Mcule.com: a public web service for drug discovery
}

\author{
Robert Kiss ${ }^{*}$, Mark Sandor, Ferenc A Szalai \\ From 7th German Conference on Chemoinformatics: 25 CIC-Workshop \\ Goslar, Germany. 6-8 November 2011
}

http://Mcule.com - a web service providing you a fast and cost-effective way to identify and order new drug candidates has been recently launched. The service is available for the public and it provides a comprehensive, carefully curated database of molecules immediately available for virtual screening. Several screening tools have been already implemented and more will be added on a weekly/monthly basis. Screening tools can be seamlessly integrated into a virtual screening workflow. Calculations are running on cloud machines providing a practically infinite number of CPUs and thus fast access to the screening results. Hits from the virtual screens can be ordered.

Publish with ChemistryCentral and every scientist can read your work free of charge

"Open access provides opportunities to our colleagues in other parts of the globe, by allowing anyone to view the content free of charge."

W. Jeffery Hurst, The Hershey Company.

- available free of charge to the entire scientific community

- peer reviewed and published immediately upon acceptance

- cited in PubMed and archived on PubMed Central

- yours - you keep the copyright

Submit your manuscript here:

http://www.chemistrycentral.com/manuscript/

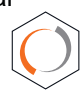

Chemistry Central 